\title{
原著
}

\section{無機質代謝に関する研究 (1)}

\section{Studies on Mineral Metabolism (1)}

\author{
日本の日常食における銅の出納状態について
}

The Observation of Copper Metabolism on Japanese Daily Diets

\section{国立栄責研究所食品化学部}

(Division of Food Chemistry, The National Institute of Nutrition)

$$
\text { 鈴木一正 (K. Suzuki) 早 川 徳子 (T. Hayakawa) }
$$

It is not yet exactly known how much copper is taken by us through the daily diet, and also the mutual relation between the actual intake of copper and its requirement is unknown.

This observation was performed as a preliminaly test of the copper balance experiments in parallel with the experiment on calcium metabolism.

No consideration was given to the copper content of the experimental diet but omitted the foods which contained rich calcium.

Five healthy women ( $A \sim D 21$ yrs. and E 40 yrs. old) were the subjects of this experiment. The copper metabolism was observed during 20 days period being divided into 4 studia of 5 days each.

Samples of the diets as well as of feces and urine corresponding to the diets were all collected and analysed.

Colorimetric method with use of dithizone was employed for the analysis of copper.

The data obtained are shown in table 3. It was found that the $7.6 \mathrm{mg}$. of copper was taken from the daily diets, and $2.4 \mathrm{mg}$. was excreted.

はしがき: 銅は, 他のいわゆる trace metal と同様に tyrosinase, butylyl Co A dehydrogenase そ の他の酵素の一部を形成する等, 生体内における必須元素の一つである事が知られているが, その生体内にお ける行動, 機能或いは要求量等に関しては未だト分に知られていないように思われる。このような元素は蛋白 質やカルシウム等の生物体を形成する元素とは異り, 人におけるその要求量も恐らく少いものであろう事は想 像されるものであるが, これまで, Tompsett, Ohlson および Daum, LevertonおよびBinkley 等によつ て人による出納実験が行われて打り, 又 Cartwright その他によつても 1 日当りの要求量として約 $2 \mathrm{mg}$ と 云う值が一応提示されている。一方, 我々の日常摂取する食品には殆どのものに銅が含まれ，純然たる食品以 外によつて銅が摂取される場合もあり，地域による食品成分の不同，食習慣による食事内容の相違等を考慮す 
ると，日本において実際にどの程度の量の銅が摄取され，それが要求量との間にどのような関係があるかと云 う事については目下の所具体的な資料汁見当らない様に思う。そこで私達は日本において日常用いられている 食事を分析してその銅含量を知り，又，一定の銅量を含屯食事文与えて人による出納試験起行い，銅の所要量 に関する資料を得たいと考えた。

今回報告するもの泣, その予備的な段階として, 当研究所において速水その他によつて行われた「女子大学 生についてのカルシウム平衡試験」に用いられた食事について銅含有量を分析し，これに伴う排泄量を求めて 銅のおおよその出納状態を調ベたものである。この場合の食事は, 銅については勿論何等の規正も行なわれて ないが，カルシウム含有量の多い食品を除いた以外は，被試験者達の喈好も入れ，日本において日常摂らてい れる食事に近くなるように献立䓘作成した。

第 1 表 1 人 1 日平均の摄取食品

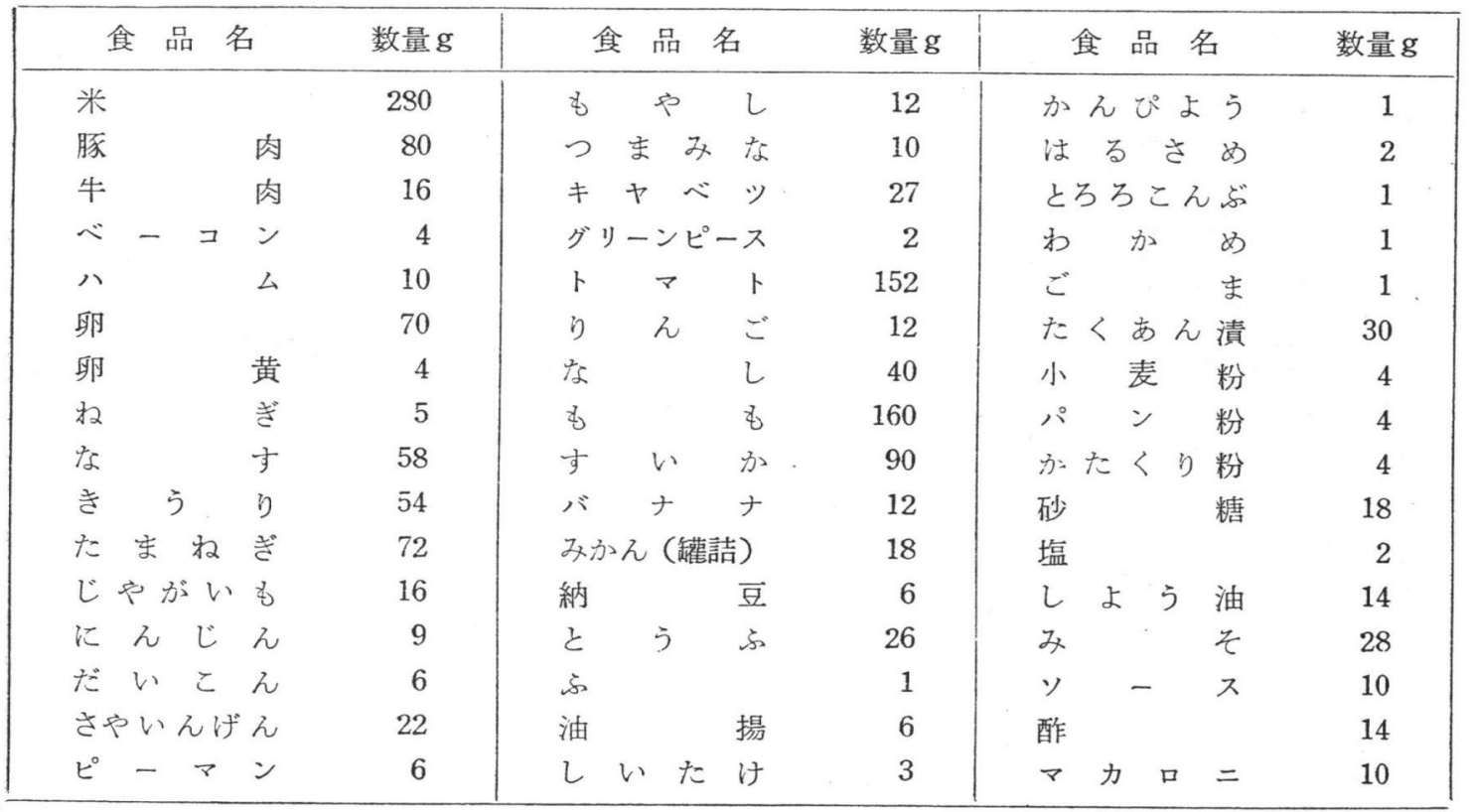

第 2 表 献 立 一例

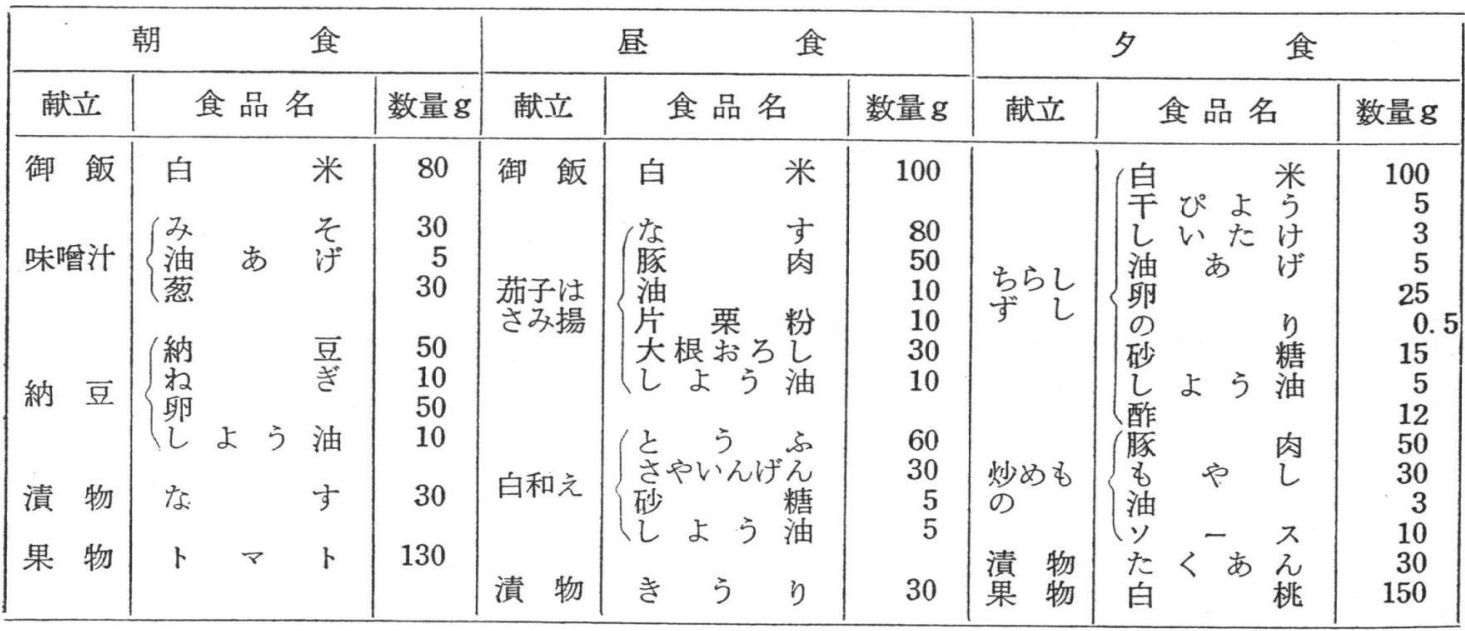


寄験：1. 被験者一健康就成年女子 5 名 第 3 表 1 人 1 日平均の銅の出納 $\mathrm{mg} / \mathrm{day}$

(A D D ) 21 才（46〜 57 kg）（女子大学 生), E 40 才 ( $45 \mathrm{~kg})$ 。

2. 実験期間一 20 日間。これを 5 日間ず つ 4 期（第 1 第 4 期）に分割。

3. 実験方法一第 1 表に示寸種類及び量 つ材料による献立 (第 2 表) の食事を 4 期 間繰り返えして各被験者に摂取させ，夫々 の期に相当する尿，屎を回収し，摂取した 食事と同一状態の標本を毎日作り, 夫ヶを 分析して銅の出納を求わた。

4. 分析一銅の分析は, 食事及び杘法乾 燥後粉末にしたものを, 尿注その儘を一定 量ずつ採り，濃硫酸，発煙硝酸及び $30 \%$ 過酸化水素水学使用し, 湿式法により灰化 したものについて dithizone 及び四塩化 炭素により銅を抽出, Beckman DU 分光 光電光度計により比色定量を行なつた。 尙, 使用した試薬類は市販の特級品岂用い た。

\begin{tabular}{|c|c|c|c|c|c|c|}
\hline \multirow{2}{*}{ 期 } & \multirow{2}{*}{ 被験者 } & \multirow{2}{*}{ 摂取量 } & \multicolumn{3}{|c|}{ 排泄 量 } & \multirow{2}{*}{ 蓄積量 } \\
\hline & & & 屎 & 尿 & 計 & \\
\hline 1 & $\begin{array}{c}\mathrm{A} \\
\mathrm{B} \\
\mathrm{C} \\
\mathrm{D} \\
\mathrm{E} \\
\text { 平均 }\end{array}$ & 7.50 & $\begin{array}{l}1.80 \\
3.00 \\
0.94 \\
1.70 \\
0.92 \\
1.67\end{array}$ & $\begin{array}{l}0.20 \\
0.24 \\
0.34 \\
0.20 \\
0.32 \\
0.26\end{array}$ & $\begin{array}{l}1.00 \\
3.24 \\
1.28 \\
1.90 \\
1.24 \\
1.93\end{array}$ & 5.57 \\
\hline 2 & $\begin{array}{r}\mathrm{A} \\
\mathrm{B} \\
\mathrm{C} \\
\mathrm{D} \\
\mathrm{E} \\
\text { 平均 }\end{array}$ & 7.50 & $\begin{array}{l}1.80 \\
3.50 \\
1.02 \\
0.84 \\
1.38 \\
1.71\end{array}$ & $\begin{array}{l}0.20 \\
0.20 \\
0.18 \\
0.11 \\
0.17 \\
0.17\end{array}$ & $\begin{array}{l}2.00 \\
3.70 \\
1.20 \\
0.95 \\
1.55 \\
1.88\end{array}$ & 5.62 \\
\hline 3 & $\begin{array}{r}\mathrm{A} \\
\mathrm{B} \\
\mathrm{C} \\
\mathrm{D} \\
\mathrm{E} \\
\text { 平均 }\end{array}$ & 7.70 & $\begin{array}{l}1.70 \\
3.10 \\
3.98 \\
- \\
3.62 \\
3.10\end{array}$ & $\begin{array}{l}0.14 \\
0.28 \\
0.34 \\
- \\
0.33 \\
0.27\end{array}$ & $\begin{array}{l}1.84 \\
3.38 \\
4.32 \\
- \\
3.95 \\
3.37\end{array}$ & 4.33 \\
\hline 4 & $\begin{array}{r}\mathrm{A} \\
\mathrm{B} \\
\mathrm{C} \\
\mathrm{D} \\
\mathrm{E} \\
\text { 平妁 }\end{array}$ & 7.50 & $\begin{array}{l}3.00 \\
3.00 \\
2.74 \\
1.30 \\
0.94 \\
2.20\end{array}$ & $\begin{array}{l}0.17 \\
0.19 \\
0.18 \\
0.17 \\
0.31 \\
0.20\end{array}$ & $\begin{array}{l}3.17 \\
3.19 \\
2.92 \\
1.47 \\
1.25 \\
2.40\end{array}$ & 5.10 \\
\hline 平 & 均 & 7.55 & 2. 17 & 0.23 & 2. 40 & 5.15 \\
\hline
\end{tabular}

実験結果 : 実験の結果，第 3 表に示す様な值が得られた。即ち，1 人 1 日平均の銅の摂取量は $7.6 \mathrm{mg}$, こ れに対する排泄量は $2.5 \mathrm{mg}$ ，結果として $5 \mathrm{mg}$ が蓄積した事になつた。

考察：以上の值を前記 Leverton 等の報告と比較した場合, 銅の摄取量としては比較的高い值を示した。 それが食品中の銅含有量の相異によるものか或いはその他の理由によるものか現在の所不明であるが，摂取し た食品のうち,トマトその他の野菜に付着した農薬類が洗滌不十分のまま食事に供せられ, 結果として銅の摄取 量が高くなる場合も考えられる。勿論この様な場合，洗滌をより十分に行なう事によつて銅量はかなり減らす 事恃可能であるが，実際の食生活状態と一致するかどうかと云う事は別問題である。目下の所一例であり，食 事の構成によつてもまた銅攝取量は異なるので, 今回は一応予備試験的な段階に止め, 普遍的な値は今後の実 験の結果にまちたいと考える。

結論：日本の日常食に近い献立による食事について銅の含量を求めたところ 1 日平均 $7.5 \mathrm{mg}$ の摂取量, こ れに対する排泄量は $2.5 \mathrm{mg}$ であつた。

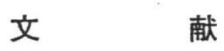

1) Tompsett, S. L. : Biochem. J. 28, 132 (1934)

2) Ohlson, M. and Daum, K. : J. Nutrition 9, 75 (1934)

3) Leverton, R. and Binkley, E. : J. Nutrition 27, 43 (1943)

4) Cartwright, G. : Am. J. Clinic. Nutrition 3, 11 (1955) 
5) "Reocommeded daily dithary allowannce"(National Reserch Council) (1958)

6) 久保彰治：栄養と食鋉 9,231 (1957)

7) 鈴木一正他: 栄養学雑誌 14,191 (1957)

8) Lindow, C. W. et al : J. Biol. Chem., 82, 465 (1929)

9) Elvehjem, C. A., and Hart, E. B. : ibid., 88, 473 (1929)

10) Remington, R.E. and Shiver, H.E. : Assoc. of Official Agricultural Chemists, 13, 129(1930)

11) Berneking, A. D., and Schrenk, W. G. : J. Agri. Food Chem. 5, 742, (1957)

12) Lapin, L. N., and Priev I. G. : ВОПРОСБІ ПИТАНИЯ 16, 62 (1957)

13）速水涣，他：国立栄湌研究所報告（昭和29年）p. 23

（受付：昭和35年 1 月 14 日）

抄—録

ピタミン $\mathrm{B}_{6}$ 欠乏ラッテのN排泄 The excretion of nitrogen by the rat in vitamin $B_{6}$ deficiency W.W. Hawkins, verna G. Lconard, Coral Maric Coles ; J. Nutrition, 69, 383 (1959)

体重 80 100g のラッテを 1 群60匹とし空素量が $5.5 \sim 5.7 \%$ 含有している飼料党用い，C群流 V. $B_{6}$ 欠乏飼料で飼育し，C群を対照として A 群㹥飼料量 をB群注体重をコントロールして夫々飼育した。又 夫々のラッテに结ビタミン類を毎日経口的に投与し た。その結果 67 ～83日後には 3 群の間に約 $15 \%$ の体 重差があらわれた。又各群の尿及び䔬中の尿素, 屁 酸, アンモニア, クレアチニン, アミノ, 窒素及び 総窒素を定量した結果は, 摈取 $\mathrm{N}$ と排泄 $\mathrm{N}$ との関係 をみたとこうろ， $\mathrm{B}_{6}$ 欠乏ラッテに於ては排泄 $\mathrm{N} の$ 堌 加がみられ, また血液中尿素の濃度が高くなり, 肝 贜の尿素の生産が増加した。

これはアミノ酸の酸化が影響しているものと考元 られる。そして著者等は $\mathrm{B}_{6}$ 欠乏ラッテの排泄 $\mathrm{N}$ の 増加はアミノ酸の酸化が影響していると指摘した。

(平山)

肉中サイアミンとリボフラビンの調理による変化 Thiamin and Riboflavin in roast beef.

Isabel noble, ph, D., Lucllegomez; J. Amer.

Dietetic Ass., 36, 46 (1960)

市販肉をローストした時の水分, 脂肪, サイアミ ン,リボフラビンを定量し、サイアミン, リボフラ ビンの調理による変化をみた。ロース肉は $149^{\circ} \mathrm{C}$ と $177^{\circ} \mathrm{C}$ のオープン中で焼きその残存率定比較した が差がなかつた。ラウンド肉, ランプ肉, ヒレ肉等
の市販肉は肉中心温度 $71^{\circ} \mathrm{C}$ で, 肉塊は $75^{\circ} \mathrm{C}$ で焼 いて長時間の加熱がこれらの栄養素の残存率纪影響 を及ぼすかを測定した。

その結果は市販肉は長時間加熱してもサイアミン の残存率洨らなかつた。

肉塊注調理によるサイアミンの残存率が平均 $70 \%$ ラウンド肉とロース肉は平均 $54 \%$ でこ 2 者の間に は有意の差があつた。ランプ肉上ヒレ肉湔 2 者の 中間の值で有意の差はなかつた。

リボフラビンについては残存率の最低は肉塊, ラ ウンド肉約 $80 \%$, 最高は約 $87 \%$ のロース肉上ランプ 肉でヒレ肉は前 2 者の中開の值を示し有意の差はな かつた。

Oestrone に対するキノコのチロシナーゼの作 用 Action of Mushroom Tyrosinase on [16${ }^{14} \mathrm{C}$ ] Oestrone P. H. Jellinck: Biochem. J. 73. 30 (1959)

キノコの抽出物又はキノコのチロシナーゼを〔16 - ${ }^{14} \mathrm{C}$ JOestrone と共にクンキュべートすると, Oestrone 中の $\mathrm{C}^{1+}$ が80 90\%水溶部分に移る, こ の反応はシアナイドや一酸化炭素で阻害される。又 血清アルブミン，血清ブロブリン，卵アルブミンの いずれを添加しても，水溶性の非透析性の物質を生 ずるこれは蛋白質と Oestrone の結合物らしく， TCA で沈澱させることが出来る。又 Oestrone の 活性は示さない。

これらの結果から Oestrone はチロシナーゼの 存在で酸化され，蛋白質と結合出来るような中間物 を生じるのであるうと思われる。

(小畠) 